\title{
THE IMPACT OF THE POL YMER COATING NUTRISPHERETM IN INCREASING NITROGEN USE EFFICIENCY AND CORN YIELD
}

\author{
${ }^{1}$ Ronnie W. Heiniger, ${ }^{1}$ Timothy A. Smith and ${ }^{2}$ Pawel Wiatrak \\ ${ }^{1}$ Department of Crop Science, North Carolina State University, Raleigh, North Carolina, USA \\ ${ }^{2}$ School of Agricultural, Forest and Environmental Sciences, Clemson University, Edisto REC, Blackville, USA
}

Received 2013-11-23; Revised 2013-12-01; Accepted 2013-12-21

\begin{abstract}
Currently, it is estimated that 50 to $60 \%$ of the $\mathrm{N}$ applied fertilizer is actually utilized by the crop with the remaining $\mathrm{N}$ lost through leaching or denitrification. A three year study was conducted at eight locations in North Carolina to examine the impact of Nutrisphere ${ }^{\mathrm{TM}}$ on corn yield, optimum $\mathrm{N}$ rate, maximum yield, tissue $\mathrm{N}$ concentration, plant biomass and $\mathrm{N}$ uptake. At six locations the study consisted of a split plot design where main plots were either 30\% Urea Ammonium Nitrate (UAN) or 30\% UAN plus Nutrisphere ${ }^{\mathrm{TM}}$ applied either at planting or layby with subplots consisting of five $\mathrm{N}$ rates that differed slightly across years. At two locations, two $\mathrm{N}$ solutions were applied at two rates to plots that received one of two starter fertilizer treatments. The overall trend indicated that Nutrisphere ${ }^{\mathrm{TM}}$ increased yield compared to the use of $30 \%$ UAN alone with a significant $(\mathrm{p}<0.10)$ yield increases of $0.74 \mathrm{Mg} \mathrm{ha}^{-1}$ from combined results at Bertie08 and Pamlico08, $0.93 \mathrm{Mg} \mathrm{ha}^{-1}$ from combined results at Guilford08 and Forsythe08 and $0.37 \mathrm{Mg} \mathrm{ha}^{-1}$ from the treatment with at planting application of $\mathrm{N}$ at Beaufort09 and Pamlico09. While Nutrisphere ${ }^{\mathrm{TM}}$ only reduced optimum $\mathrm{N}$ rate in two trials, there was a consistent increase in maximum potential yield across trials. Plant analysis found that Nutrisphere ${ }^{\mathrm{TM}}$ increased biomass at one location, although it did not affect tissue $\mathrm{N}$ concentration and did not result in consistent increases in plant $\mathrm{N}$ uptake. The significant impacts of Nutrisphere ${ }^{\mathrm{TM}}$ on plant biomass and corn yield indicate that it affects the $\mathrm{N}$ movement to the root surface over a short period of time after application. More research is needed to determine how Nutrisphere ${ }^{\mathrm{TM}}$ impacts $\mathrm{N}$ movement in the soil, $\mathrm{N}$ transformations and $\mathrm{N}$ uptake to improve recommendations regarding its use and potential for increasing yield.
\end{abstract}

Keywords: Nitrogen, Nitrogen Use Efficiency, Polymer Fertilizer Coating, Urea Ammonium Nitrate (UAN), Nutrisphere ${ }^{\mathrm{TM}}$

\section{INTRODUCTION}

Current trends in population growth indicate that by 2050 there will be over 8.9 billion people on this planet (FAO, 2004). To provide adequate food, fiber and renewable energy resources to meet this growth in population, we will need todramatically increase crop yields. Increasing yields, particularly in cereal crops, will require the increased use of plant nutrients such as Nitrogen $(\mathrm{N})$ applied in the form of fertilizers. Corresponding Author: Ronnie W. Heiniger, Department of Crop Science, North Carolina State University, Raleigh, North Carolina, USA
Unfortunately, concerns about the impact of $\mathrm{N}$ fertilizers on aquatic ecosystems, water quality (Hubbard and Sheridan, 1989) and climate change (Jarecki et al., 2008) make it imperative that the use of these fertilizers be properly managed. Currently, it is estimated that 50 to $60 \%$ of applied $\mathrm{N}$ fertilizer is actually used by the crop with the remaining $\mathrm{N}$ lost through leaching or denitrification (Blackmer and Schepers, 1996). Improving the use efficiency of $\mathrm{N}$ fertilizers is the key to increasing yield without increasing the amount of $\mathrm{N}$ 
fertilizer applied. New fertilizer additives that improve $\mathrm{N}$ uptake or reduce $\mathrm{N}$ losses offer the potential to improve $\mathrm{N}$ use efficiency.

While there are several fertilizer products that contain $\mathrm{N}$, in the southeastern US Urea Ammonium Nitrate (UAN) containing either 30 or $32 \% \mathrm{~N}$ has become the primary $\mathrm{N}$ fertilizer (NASS, 2009). This is mostly due to availability, cost and ease of transportation. Half of the $\mathrm{N}$ in UAN is in the form of urea, which can be lost through volatilization when applied on the soil surface where the surface $\mathrm{pH}$ is above 6.5 (Vaio et al., 2008). The remaining $\mathrm{N}$ in UAN is in the form of ammonium nitrate. While the ammonium in this molecule bonds readily to soil colloids, Nitrate $\left(\mathrm{NO}_{3}-\mathrm{N}\right)$ component is highly soluble and can be lost through leaching or surface runoff (Stevenson and Baldwin, 1969).

Several practices could be used to improve the $\mathrm{N}$ use efficiency of fertilizer like UAN. For instance, UAN could be applied close to the root system to avoid volatilization and assure rapid uptake by the plant before heavy rainfall carries it away or moves fertilizer deeper in the soil (Stevenson and Baldwin, 1969). Unfortunately, narrow row crops and weather conditions such as wet and muddy soils can make it difficult to place fertilizer close to growing roots. Another approach would be to use controlled release fertilizers or fertilizer additives that could improve plant uptake through increasing the availability and timing of $\mathrm{N}$ release to match the need of the plant. For instance, by controlling the conversion of ammonium to nitrate more of $\mathrm{N}$ could be retained on the soil colloids. Also, more $\mathrm{N}$ would move through mass flow to root surfaces by increasing the solubility of urea or nitrate in water. While the potential advantages of these fertilizer additives or controlled release fertilizers include higher $\mathrm{N}$ concentrations in the root zone, less leaching of nutrients, longer nutrient supply, reduced volatilization of $\mathrm{N}$ and matched release rates with crop nutrient demand compared to conventional fertilizers, these materials currently account for a fraction of fertilizer use (Trenkel, 1997). The primary reason for this is the lack of evidence indicating the efficacy of fertilizer additives or controlled release fertilizers in achieving these advantages.

Fertilizer additive, released by Specialty Fertilizer Products, Inc. (Lenexa, KS), has the potential to overcome problems associated with weather and management by increasing yield and improving $\mathrm{N}$ use efficiency over a wide range of environmental conditions. Nutrisphere $\mathrm{TM}^{\mathrm{T}}$ is a long chain branched polymer with a large negative charge (1800 meq 100 $\left.\mathrm{g}^{-1}\right)$. This charge makes the molecules table at high ionic concentrations, which allows to hold other molecules in suspension. Adding it to a fertilizer like UAN, Nutrisphere ${ }^{\mathrm{TM}}$ coats the fertilizer molecule. In the soil, the Nutrisphere ${ }^{\mathrm{TM}}$ coating binds to positively charged cations such as nickel, so these cations will no longer be available in forming the urease enzyme. Without the urease enzyme the hydrolization of urea or nitrate into ammonia ceases. Since this mechanism is the primary pathway for conversion of $\mathrm{N}$ in the soil, efficacy of this material would be less sensitive to environmental or management conditions.

Generally, growing conditions in this study were less than ideal, which limited potential yield and influence of $\mathrm{N}$. More studies are needed to determine if Nutrisphere ${ }^{\mathrm{TM}}$ is effective in increasing yield and $\mathrm{N}$ use efficiency either by controlling $\mathrm{N}$ release or by improving early uptake and crop growth. The objectives of this study were to: (1) examine the impact of the fertilizer additive Nutrisphere ${ }^{\mathrm{TM}}$ on yield in high population corn systems, (2) determine if Nutrisphere ${ }^{\mathrm{TM}}$ influences optimum $\mathrm{N}$ rate or maximum yield in corn and (3) determine if Nutrisphere ${ }^{\mathrm{TM}}$ affects plant tissue $\mathrm{N}$ concentration, biomass, or $\mathrm{N}$ uptake.

\section{MATERIALS AND METHODS}

\subsection{Site Preparation and Management}

Nine research trails were conducted in 2007, 2008 and 2009 at locations in Pamlico, Beaufort, Currituck, Guilford, Forsythe and Bertie Counties on wide range of soil types (Table 1). The key purpose of these trials was to test the impact of polymer fertilizer additive Nutrisphere $^{\mathrm{TM}}$ marketed by Specialty Fertilizer Products, Inc. on $\mathrm{N}$ use efficiency and yield in corn. At two locations, Nutrisphere $^{\mathrm{TM}}$ was tested in a combined study along with the polymer Avail ${ }^{\mathrm{TM}}$ which was added to a blended liquid fertilizer with N, Phosphorus (P) and Potassium (K) and applied as a starter. Avail ${ }^{\mathrm{TM}}$ is a high-exchange polymer similar to Nutrisphere ${ }^{\mathrm{TM}}$ and composed of long-chain molecules with highly active adsorbent sites.

\subsection{Methods}

At the Pamlico07 and Currituck07 locations the experimental design was a split plot with four replications. Two main plot treatments were $30 \%$ UAN and $30 \%$ UAN with Nutrisphere ${ }^{\mathrm{TM}}$ added at the recommended rate of $0.005 \mathrm{~L} \quad 1 \quad \mathrm{~L}^{-1}$. Subplots consisted of four application rates in order to achieve $0,56,91,161$ and $303 \mathrm{~kg} \mathrm{~N} \mathrm{ha}^{-1}$. 
Table 1. Soil and crop management information for Nutrisphere ${ }^{\mathrm{TM}}$ research trials in 2007, 2008 and 2009

\begin{tabular}{llll}
\hline Location & Soil Taxonomic Class & Planting & \\
date & Hybrid \\
\hline Pamlico07 & Fine-loamy, mixed, semiactive, acid, thermic Histic Humaquept & 28-Mar-07 & 'DKC69-71' \\
Currituck07 & Coarse-silty, mixed, semiactive, thermic Typic Endoaquult & Apr. 3, 2007 & 'Pioneer 31G98' \\
Forsythe08 & Fine, kaolinitic, thermic Rhodic Kanhapludult & 2-May-08 & 'DKC61-69' \\
Guilford08 & Coarse-loamy, siliceous, subactive, thermic Aquic Hapludult & 3-May-08 & 'DKC61-69' \\
Bertie08 & Fine-loamy, siliceous, subactive, thermic Aquic Paleudult & 15-Apr-08 & 'DKC61-69' \\
Pamlico08 & Fine-loamy, mixed, active, thermic Typic Endoaqualf & 11-Apr-08 & 'Pioneer 31G96' \\
Beaufort09 & Fine, mixed, semiactive, thermic Typic Endoaquult & 21-Apr-09 & 'Pioneer 31P42' \\
Pamlico09 & Fine-loamy, mixed, active, thermic Typic Endoaqualf & 8-Apr-09 & 'Pioneer 31P44' \\
\hline
\end{tabular}

Fertilizer was broadcast applied following corn planting. The purpose for making the application at planting was to insure that adequate $\mathrm{N}$ was available for early plant growth. At each location, 17-17-0 fertilizer was applied to all plots at planting in a $2 \times 2$ band at a rate of $90.4 \mathrm{~L} \mathrm{ha}^{-1}$.

\subsection{Methods}

At the Guilford08 and Forsythe08 sites, the Nutrisphere ${ }^{\mathrm{TM}}$ polymer test was evaluated with starter fertilizer with and without Avail ${ }^{\mathrm{TM}}$ using a randomized complete block design with four replications. Ten treatments were applied: (A) 12-12-4 applied as a starter in a $2 \times 2$ band with $30 \%$ UAN broadcast applied at 143 $\mathrm{kg} \mathrm{N} \mathrm{ha}{ }^{-1}$, (B) $12-12-4$ in a $2 \times 2$ band with $30 \%$ UAN broadcast applied at $179 \mathrm{~kg} \mathrm{~N} \mathrm{ha}^{-1}$, (C) $12-12-4$ in a $2 \times 2$ band with $30 \%$ UAN plus Nutrisphere broadcast applied at $143 \mathrm{~kg} \mathrm{~N} \mathrm{ha}^{-1}$, (D) $12-12-4$ in a $2 \times 2$ band with $30 \%$ UAN plus Nutrisphere broadcast at $179 \mathrm{~kg} \mathrm{~N} \mathrm{ha}^{-1}$, (E) $12-12-4$ in a $2 \times 2$ band with Avail plus $30 \%$ UAN broadcast applied at $143 \mathrm{~kg} \mathrm{~N} \mathrm{ha}^{-1}$, (F) 12-12-4 in a $2 \times 2$ band with Avail with $30 \%$ UAN broadcast applied at 179 $\mathrm{kg} \mathrm{N} \mathrm{ha}^{-1},(\mathrm{G}) 12-12-4$ with Avail in a $2 \times 2$ band with $30 \%$ UAN plus Nutrisphere broadcast applied at $143 \mathrm{~kg} \mathrm{~N} \mathrm{ha}^{-1}$, (H) 12-12-4 with Avail in a $2 \times 2$ band with $30 \%$ UAN plus Nutrisphere broadcast applied at $179 \mathrm{~kg} \mathrm{~N}^{-1}$, (I) no starter fertilizer with $30 \%$ UAN broadcast applied at 179 $\mathrm{kg} \mathrm{N} \mathrm{ha}{ }^{-1}$ and (J) no fertilizer applied. The Avail ${ }^{\mathrm{TM}}$ polymer was added to the $12-12-4$ at a rate of $0.005 \mathrm{~L} 1$ $\mathrm{L}^{-1}$. The starter fertilizer with or without Avail ${ }^{\mathrm{TM}}$ was applied a rate of $187 \mathrm{~L} \mathrm{ha}^{-1}$. The Nutrisphere ${ }^{\mathrm{TM}}$ polymer

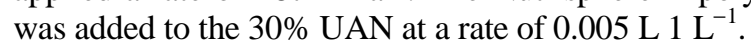

At Pamilco08 and Bertie08 locations, Nutrisphere ${ }^{\mathrm{TM}}$ was evaluated using a split plot design with four replications. Main plot treatments consisted of either $30 \%$ UAN or $30 \%$ UAN plus Nutrisphere ${ }^{\mathrm{TM}}$ applied at $0.005 \mathrm{~L}^{1} \mathrm{~L}^{-1}$ as a layby application. Subplot treatments were application rates of $0,34,90$, 202, 258 and $314 \mathrm{~kg} \mathrm{~N} \mathrm{ha}^{-1}$. At both of these locations, treatments were applied at V7. Starter fertilizer was applied in the form of $10-27-0$ at a rate of $90.4 \mathrm{~L} \mathrm{ha}^{-1}$ in a $2 \times 2$ band at planting. In addition to the starter, fertilizer $37 \mathrm{~kg} \mathrm{~N} \mathrm{ha}{ }^{-1}$ was broadcast applied to all of the plots at planting using $30 \%$ UAN.

\subsection{Methods}

The Nutrisphere ${ }^{\mathrm{TM}}$ polymer additive was tested at two sites in 2009: Pamlico09 and Beaufort09 (Table 1). The experimental design was a split-split plot with three replications. Main plots consisted of a broadcast treatment of either $30 \%$ UAN, or $30 \%$ UAN plus Nutrisphere $^{\mathrm{TM}}$ mixed at $0.005 \mathrm{~L} \quad 1 \mathrm{~L}^{-1}$. Subplot treatments were two application dates, either at-planting (21 April) or at-layby (27 May). Sub-subplots consisted of five application rates of 0,101, 146, 202 and $258 \mathrm{~kg} \mathrm{~N}$ $\mathrm{ha}^{-1}$. No starter fertilizer was applied at either of these locations in 2009. Whole plant tissue samples were collected at growth stages V5 (27 May at Beaufort09 and 21 May at Pamlico09) and whole plant tissue samples, above ground biomass and $\mathrm{N}$ uptake were measured at R1 (27 June at Beaufort09 and 26 June at Pamlico09) from $\mathrm{N}$ application treatments at planting except the highest $\mathrm{N}$ rate. In addition, stalk samples were collected at harvest by clipping a $15 \mathrm{~cm}$ portion of stalk from just above the soil surface. Tissue and stalk samples consisted of five consecutive plants collected from a random sampling of the outside rows of each plot. Samples were chopped and dried and biomass was measured at R1 and sent to the North Carolina Department of Agriculture and Consumer Services (NCDA\&CS) laboratory in Raleigh, NC for analyses using standard procedures for testing total \% Kjehdal $\mathrm{N}$ (Nelson and Summers, 1973).

\subsection{Common Methods}

Planting dates and hybrids for each test are shown in Table 1. Corn was planted in $0.76 \mathrm{~m}$ row spacing and seeding rate of 81,510 seeds $\mathrm{ha}^{-1}$. For all locations and years, plots consisted of four rows of corn that were 3.08 $\mathrm{m}$ wide and $12.3 \mathrm{~m}$ long. Bicep ( $S$-metolachlor+6chloro- $N$-ethyl- $N$ '-isopropyl-1,3,5-triazine-2,4-diamine) 
applied at recommended rates at planting and Roundup (N-phosphonomethyl glycine) and atrazine (6-chloro- $N$ ethyl- $N$ '-isopropyl-1,3,5-triazine-2,4-diamine) applied at recommended rates at layby provided excellent weed control. Insects and diseases (with the exception of the Pamlico07 location) were not a factor. The center two rows of each four row plot were harvested in September using a Gleaner $\mathrm{K} 2$ combine with a Harvestmaster ${ }^{\mathrm{TM}}$ system (Juniper Systems, Inc., UT) that recorded grain weight, moisture and test weight for each plot.

\subsection{Data Analyses}

All data were analyzed using PROC Mixed (SAS, 2005) with replicated blocks considered as random factors. Mean separations of interest were done using contrast statements. To determine economically optimum $\mathrm{N}$ rate grain yield response to $\mathrm{N}$ was modeled as a quadratic-plateau function using PROC NLIN (SAS, 2005). Economic optimum $\mathrm{N}$ rates were calculated using a price ratio of $7: 1$, where the price ratio was defined as the ratio of the price per $\mathrm{Mg} \mathrm{N}$ to the price per $\mathrm{Mg}$ of corn. If any of the responses did not fit a quadratic-plateau function determined by the significance of the model at an alpha of 0.05 , then treatment means were compared using contrast statements to determine the optimum $\mathrm{N}$ level. If the yield response to fertilizer $\mathrm{N}$ was not significant as measured by either of the above methods, the economic optimum $\mathrm{N}$ was set equal to zero.

\section{RESULTS}

\subsection{Yield Comparisons}

Differences in study design ( $\mathrm{N}$ rates) from year-toyear eliminated the possibility of combining results across years. However, results were combined within years with the exception of Guilford08 and Forsythe08 locations, which were analyzed as a unit because they included starter fertilizer treatments with and without Avail $^{\mathrm{TM}}$. In 2007 at the Pamlico07 and Currituck07 sites the combined analysis found a location by rate interaction $(p=0.0022)$ and a significant rate effect $(\mathrm{p}<0.0001)$. At both locations yield increased as $\mathrm{N}$ rate increased (Table 2). However, maximum corn yield was higher at Pamlico07 resulting in larger differences in yield among the $\mathrm{N}$ rates (Fig. 1). While the source by rate interaction was not significant $(p=0.1733)$ contrast statements indicated differences in corn yield between $30 \%$ UAN and $30 \%$ UAN plus Nutrisphere ${ }^{\mathrm{TM}}$ when either 90 or the highest rate of $303 \mathrm{~kg} \mathrm{~N} \mathrm{ha}^{-1}$ were applied.
In 2008, at the Bertie08 and Pamlico08 sites there was a significant location by rate $(\mathrm{p}=0.0059)$ interaction and significant rate $(\mathrm{p}=0.0055)$, source $(\mathrm{p}=0.0067)$ and location $(\mathrm{p}=0.0016)$ main effects. Severe drought at the Bertie08 location resulted in no yield response to added $\mathrm{N}$. This resulted in significantly different yield levels and yield responses (Fig. 2). Across the two locations, addition of Nutrisphere ${ }^{\mathrm{TM}}$ resulted in a significant yield increase of $0.74 \mathrm{Mg} \mathrm{ha}^{-1}$ and contrast statements indicated significant increases in yield between the two $\mathrm{N}$ solutions when either 202 or $258 \mathrm{~kg} \mathrm{~N} \mathrm{ha}^{-1}$ were applied (Table 2).

At the Forsythe08 and Guilford08 locations, statistical analysis found a strong treatment effect $(\mathrm{p}=$ 0.0011). Contrast statements examined differences between $30 \%$ UAN and $30 \%$ UAN with Nutrisphere ${ }^{\mathrm{TM}}$. There was a significant yield increase $(\mathrm{p}=0.0152)$ of $0.93 \mathrm{Mg} \mathrm{ha}^{-1}$ resulting from the use of Nutrisphere ${ }^{\mathrm{TM}}$ whenever starter fertilizer (either 12-12-4 or 12-12-4 with Avail ${ }^{\mathrm{TM}}$ ) was applied (Fig. 3). However, there was no significant difference between the two $\mathrm{N}$ solutions within either the 12-12-4 application or the application of 12-12-4 with Avail ${ }^{\mathrm{TM}}$.

In 2009, when the Pamlico09 and Beaufort09 locations were analyzed together, there were strong location by rate $(\mathrm{p}<0.0001)$ and application timing by source $(\mathrm{p}=0.0124)$ interactions. As in the earlier trials, corn yield at both locations increased as the rate of $\mathrm{N}$ applied increased. It was the rate at which yield increased at each location that resulted in the location by rate interaction (Fig. 4). Adding Nutrisphere ${ }^{\mathrm{TM}}$ to $30 \%$ UAN and applied at planting produced a significant yield increase of $0.37 \mathrm{Mg} \mathrm{ha}^{-1}$ and contrast statements found a significant yield increase when Nutrisphere ${ }^{\mathrm{TM}}$ was applied with $30 \%$ UAN at a rate of $101 \mathrm{~kg} \mathrm{~N} \mathrm{ha}^{-1}$ (Table 2). No significant yield differences between $30 \%$ UAN and $30 \%$ UAN plus Nutrisphere ${ }^{\mathrm{TM}}$ were found with applications made at layby.

\subsection{Optimum $\mathbf{N}$ Rate and Maximum Yield}

At the Currituck07 location when $30 \%$ UAN was used alone and at the Bertie08 location when either $30 \%$ UAN or $30 \%$ UAN plus Nutrisphere ${ }^{\mathrm{TM}}$ were used, the yield responses to added $\mathrm{N}$ did not fit quadraticplateau functions (Fig. 1 and 2). Therefore, optimum $\mathrm{N}$ rates and maximum yields at these locations and $\mathrm{N}$ sources were determined by using contrast statements to find the $\mathrm{N}$ rate that produced the highest yield at $\mathrm{p}<0.05$. Both Currituck07 and Bertie 08 experienced extremely dry conditions during the respective growing seasons in 2007 and 2008, which contributed to the lack of a yield response to added $\mathrm{N}$. 


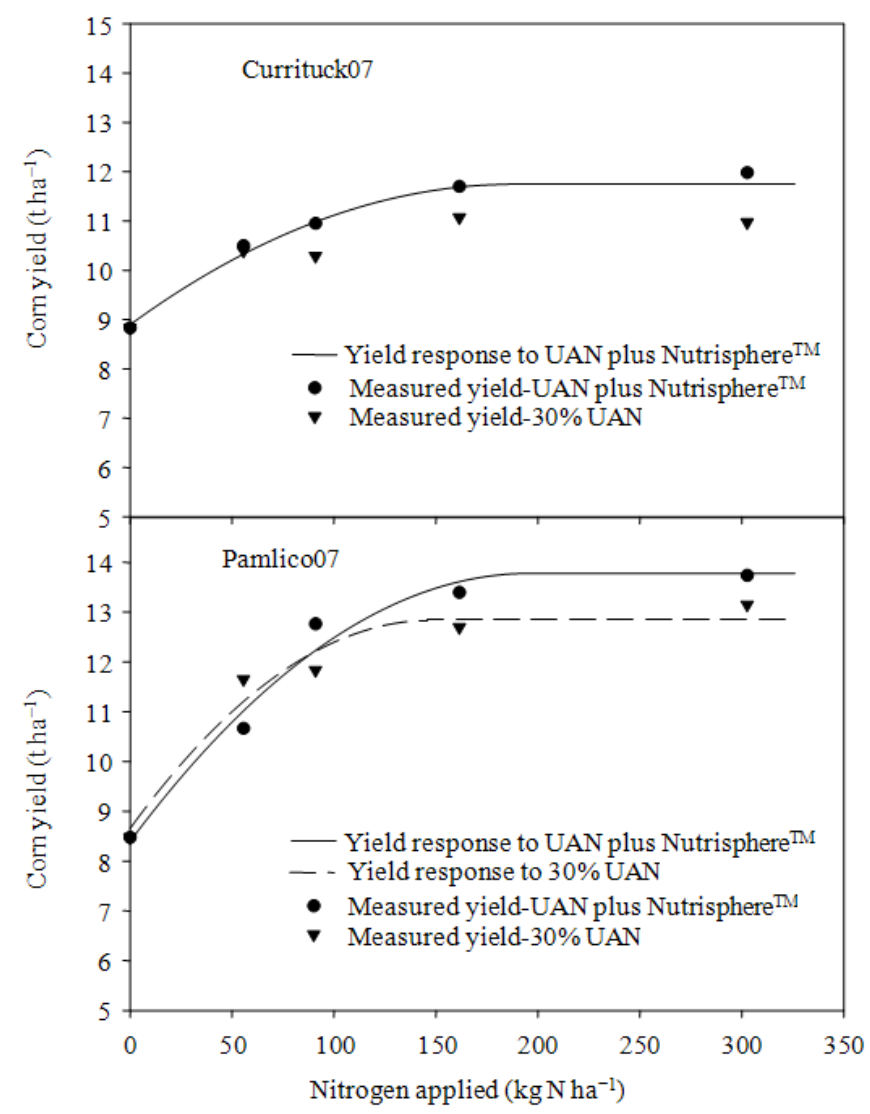

Fig. 1. Corn yield response to $30 \%$ UAN applied with or without Nutrisphere ${ }^{\mathrm{TM}}$ at planting at two locations in 2007. Lines represent a quadratic-plateau model fit to the replicated data from each $\mathrm{N}$ rate applied. Points represent the average grain yield at each $\mathrm{N}$ rate applied. If a line is not shown, a quadratic-plateau model did produce a significant $(\mathrm{p}<0.05)$ fit at that location and $\mathrm{N}$ solution

Table 2. Corn yield response to $30 \%$ UAN with and without Nutrisphere ${ }^{\mathrm{TM}}$ at five nitrogen rates that differ across years

\begin{tabular}{|c|c|c|c|c|c|c|c|}
\hline \multirow{3}{*}{$\begin{array}{l}\text { Timing/ } \\
\text { Year }\end{array}$} & \multirow{3}{*}{$\begin{array}{l}\text { Nitrogen } \\
\text { treatment }\end{array}$} & \multicolumn{5}{|c|}{ Nitrogen rate code $\dagger$} & \multirow[b]{3}{*}{ Average } \\
\hline & & \multicolumn{5}{|l|}{$\mathrm{Mg} \mathrm{ha}^{-1}$} & \\
\hline & & 0 & 1 & 2 & 3 & 4 & \\
\hline \multirow[t]{2}{*}{ Plant 07} & $30 \%$ UAN & 8.65 & $11.02 \mathrm{a} \ddagger$ & $11.06 \mathrm{a}$ & $11.88 \mathrm{a}$ & $12.06 \mathrm{a}$ & $10.93 \mathrm{~A} \S$ \\
\hline & UAN + Nutrisphere ${ }^{\mathrm{TM}}$ & 8.65 & $10.58 \mathrm{a}$ & $11.86 \mathrm{~b}$ & $12.55 \mathrm{a}$ & $12.86 \mathrm{~b}$ & $11.30 \mathrm{~A}$ \\
\hline $\mathrm{N}$ rate averages & $8.65 \mathrm{a} \|$ & $10.80 \mathrm{~b}$ & $11.46 \mathrm{c}$ & $12.21 \mathrm{~d}$ & $12.46 \mathrm{~d}$ & & \\
\hline \multirow[t]{2}{*}{ Layby 08} & $30 \%$ UAN & $5.54 \mathrm{a}$ & $6.28 \mathrm{a}$ & $6.12 \mathrm{a}$ & $6.89 \mathrm{a}$ & $7.19 \mathrm{a}$ & $6.40 \mathrm{~A}$ \\
\hline & UAN + Nutrisphere ${ }^{\mathrm{TM}}$ & $6.40 \mathrm{a}$ & $6.79 \mathrm{a}$ & $7.22 b$ & $8.08 \mathrm{~b}$ & $7.23 \mathrm{a}$ & $7.14 \mathrm{~B}$ \\
\hline $\mathrm{N}$ rate averages & $5.97 \mathrm{a}$ & $6.54 \mathrm{ab}$ & $6.67 \mathrm{bd}$ & $7.48 \mathrm{c}$ & $7.21 \mathrm{~cd}$ & & \\
\hline \multirow[t]{2}{*}{ Plant 09} & $30 \%$ UAN & 7.41 & $11.02 \mathrm{a}$ & $11.68 \mathrm{a}$ & $13.24 \mathrm{a}$ & $13.18 \mathrm{a}$ & $11.30 \mathrm{~A}$ \\
\hline & UAN + Nutrisphere ${ }^{\mathrm{TM}}$ & 7.41 & $11.71 \mathrm{~b}$ & $12.15 \mathrm{a}$ & $13.61 \mathrm{a}$ & $13.50 \mathrm{a}$ & $11.67 \mathrm{~B}$ \\
\hline $\mathrm{N}$ rate averages & $7.41 \mathrm{a}$ & $11.37 \mathrm{~b}$ & $11.91 \mathrm{c}$ & $13.42 \mathrm{~d}$ & $13.34 \mathrm{~d}$ & & \\
\hline \multirow[t]{2}{*}{ Layby 09} & $30 \%$ UAN & 7.11 & $11.37 \mathrm{a}$ & $12.51 \mathrm{a}$ & $13.39 \mathrm{a}$ & $13.44 \mathrm{a}$ & $11.09 \mathrm{~A}$ \\
\hline & UAN + Nutrisphere ${ }^{\mathrm{TM}}$ & 7.11 & $11.51 \mathrm{a}$ & $12.32 \mathrm{a}$ & $13.62 \mathrm{a}$ & $13.87 \mathrm{a}$ & $11.14 \mathrm{~A}$ \\
\hline $\mathrm{N}$ rate averages & $7.11 \mathrm{a}$ & $11.44 \mathrm{~b}$ & $12.42 \mathrm{c}$ & $13.50 \mathrm{~d}$ & $13.65 \mathrm{~d}$ & & \\
\hline
\end{tabular}

$\dagger$ Nitrogen rates for each year were: $2007-0=0,1=56,2=91,3=161$ and $4=303 \mathrm{~kg} \mathrm{~N} \mathrm{ha}^{-1} ; 2008-0=34,1=90,2=202,3=258$ and $4=314 \mathrm{~kg} \mathrm{~N} \mathrm{ha}^{-1} ; 2009-0=0,1=101,2=146,3=202$ and $4=258 \mathrm{~kg} \mathrm{~N} h a^{-1}$; $\ddagger$ Different letters within each year and rate code column indicate significant differences at $\mathrm{p}<0.10$. § Different letters within each year under the Average column indicate significant differences between $30 \%$ UAN and $30 \%$ UAN plus Nutrisphere ${ }^{\mathrm{TM}}$ at $\mathrm{p}<0.10$; I Different letters within each row showing the $\mathrm{N}$ rate averages indicate significant differences at $\mathrm{p}<0.10$ 


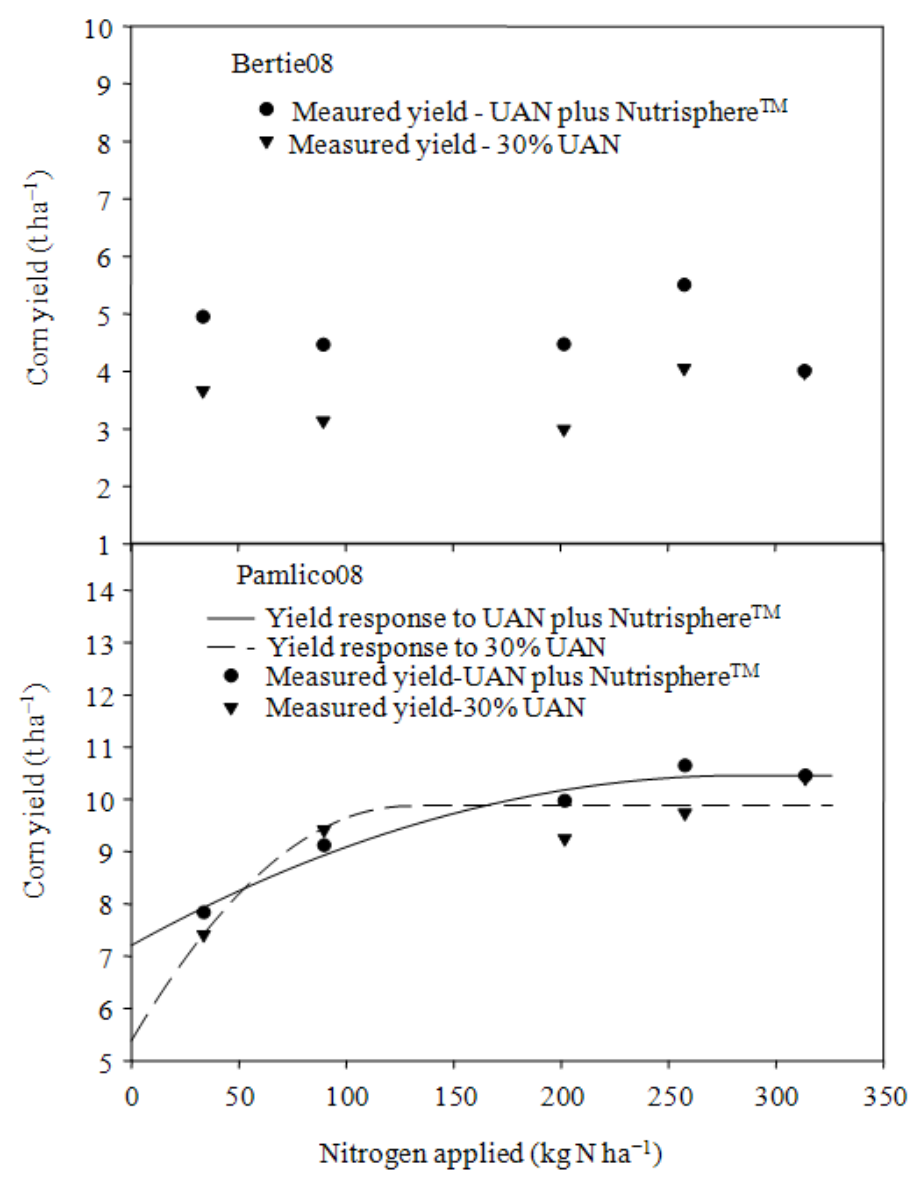

Fig. 2. Corn yield response to $30 \%$ UAN applied with or without Nutrisphere ${ }^{\mathrm{TM}}$ at layby at two locations in 2008. Lines represent a quadratic-plateau model fit to the replicated data from each $\mathrm{N}$ rate applied. Points represent the average grain yield at each $\mathrm{N}$ rate applied. If a line is not shown, quadratic-plateau model did produce a significant $(\mathrm{p}<0.05)$ fit at that location and $\mathrm{N}$ solution

Table 3. Optimum nitrogen rates and maximum yield predicted by a quadratic-plateau model fit to the grain yield response to five rates of 30\% UAN with and without Nutrisphere ${ }^{\mathrm{TM}}$ applied at different times and locations across North Carolina

\begin{tabular}{|c|c|c|c|c|c|}
\hline \multirow[b]{3}{*}{$\begin{array}{l}\text { Location/Year } \\
\text { Currituck07 }\end{array}$} & \multirow[b]{3}{*}{$\begin{array}{l}\text { Application timing } \\
\text { planting }\end{array}$} & \multicolumn{2}{|l|}{ Optimum $\mathrm{N}$ rate } & \multicolumn{2}{|c|}{ Predicted maximum yield } \\
\hline & & \multicolumn{2}{|l|}{$\mathrm{kg} \mathrm{N} \mathrm{ha}^{-1}$} & \multicolumn{2}{|l|}{$\mathrm{Mg} \mathrm{ha}^{-1}$} \\
\hline & & $\begin{array}{l}\text { Nutrisphere }{ }^{\mathrm{TM}} \dagger \\
145\end{array}$ & $\begin{array}{l}30 \% \text { UAN } \\
56.0 \ddagger\end{array}$ & $\begin{array}{l}\text { Nutrisphere }{ }^{\mathrm{TM}} \\
11.7\end{array}$ & $\begin{array}{l}30 \% \text { UAN } \\
10.4\end{array}$ \\
\hline $\begin{array}{l}\text { Pamlico07 } \\
\text { Pacol }\end{array}$ & Planting & 171.1 & 130 & 13.8 & 12.8 \\
\hline Bertie08 & Layby & $0 \ddagger$ & $0 \ddagger$ & 5.0 & 3.7 \\
\hline Pamlico08 & Layby & 197.5 & 115.9 & 10.5 & 9.9 \\
\hline Beaufort09 & Planting & 196.7 & 217.5 & 14.3 & 13.8 \\
\hline Pamlico09 & Planting & 212.5 & 253.9 & 12.6 & 13.3 \\
\hline Beaufort09 & Layby & 234.3 & 186.5 & 14.9 & 14.1 \\
\hline Pamlico09 & Layby & 217.3 & 218.5 & 12.8 & 12.8 \\
\hline
\end{tabular}

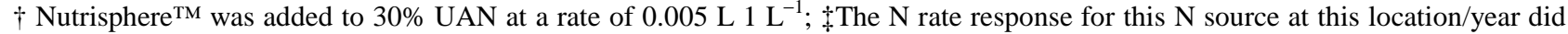
not fit a quadratic-plateau model. Optimum $\mathrm{N}$ rate and maximum yield were determined using contrast statements to find the lowest $\mathrm{N}$ rate that produced the highest yield at $\mathrm{p}<0.05$ 
Ronnie W. Heiniger et al. / American Journal of Agricultural and Biological Sciences 9 (1): 44-54, 2014

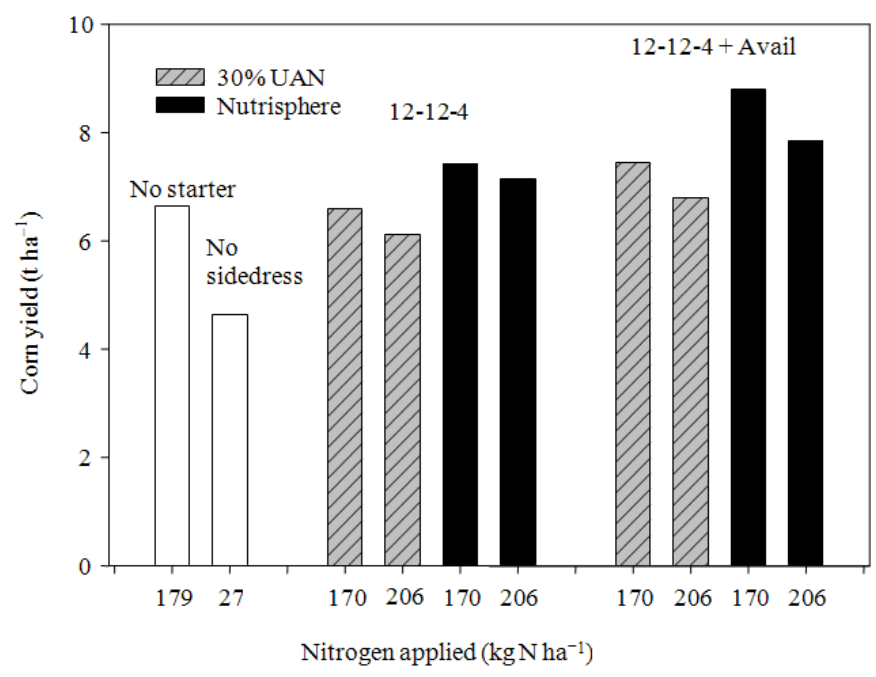

Fig. 3. Grain yield measured with various treatments including either no starter, $12-12-4$, or $12-12-4$ plus Avail ${ }^{\mathrm{TM}}$ applied in a $2 \times 2$ band at planting and layby application of either $30 \%$ UAN or $30 \%$ UAN with added Nutrisphere ${ }^{\mathrm{TM}}$. Contrast statements found that when either 12-12-4 or 12-12-4 with Avail ${ }^{\mathrm{TM}}$ was used, Nutrisphere ${ }^{\mathrm{TM}}$ added to $30 \%$ UAN significantly increased corn yield compared to the use of $30 \%$ UAN alone at $\mathrm{p}=0.0152$

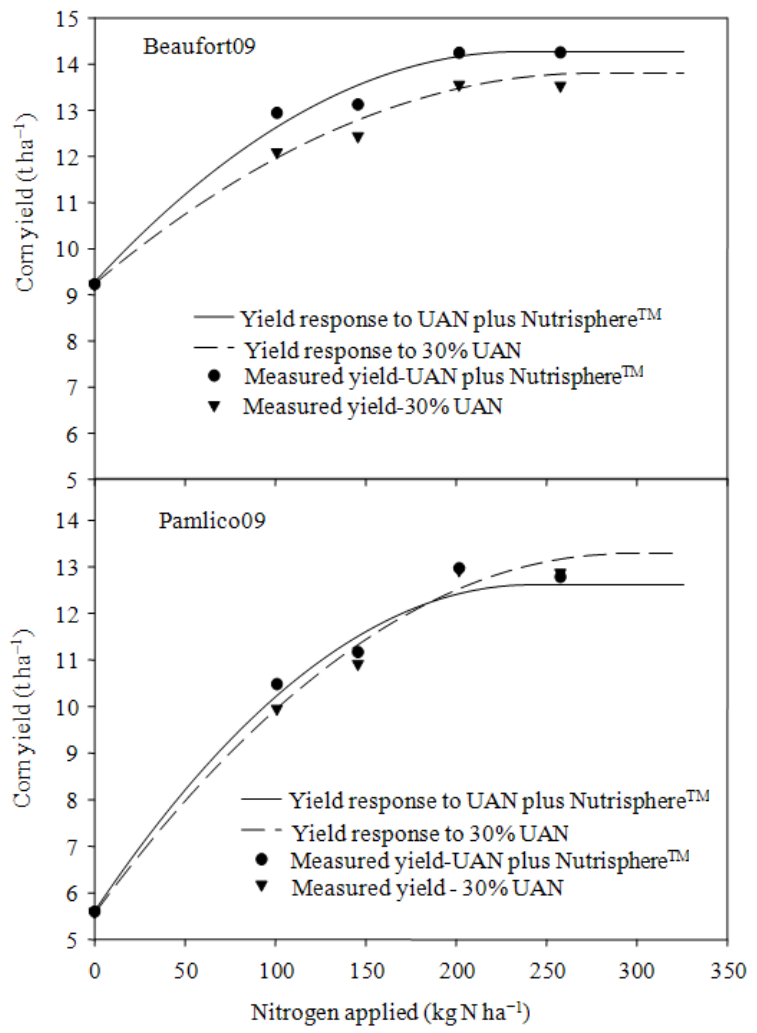

Fig. 4. Corn yield response to $30 \%$ UAN applied with or without Nutrisphere ${ }^{\mathrm{TM}}$ at planting at two locations in 2009. Lines represent a quadratic-plateau model fit to the replicated data from each $\mathrm{N}$ rate applied. Points represent the average grain yield at each $\mathrm{N}$ rate applied. If a line is not shown, quadratic-plateau model did produce a significant $(\mathrm{p}<0.05)$ fit at that location and $\mathrm{N}$ solution 
Across the eight trials where a range of $\mathrm{N}$ rates were applied, $30 \%$ UAN resulted in lower optimum $\mathrm{N}$ rates in four trials, while Nutrisphere ${ }^{\mathrm{TM}}$ added to $30 \%$ UAN resulted in lower optimum $\mathrm{N}$ rates in two trials and there was only a slight (less than $2 \mathrm{~kg} \mathrm{~N} \mathrm{ha}^{-1}$ ) difference between the $\mathrm{N}$ solutions in one trial at Pamlico09 when the materials were applied at layby (Table 3). In six out of eight trials, Nutrisphere ${ }^{\mathrm{TM}}$ added to $30 \%$ UAN resulted in higher maximum yield when compared to $30 \%$ UAN alone as indicated by the quadratic-plateau model or statistical comparisons of yield among applied $\mathrm{N}$ rates. The indicated yield advantage to the use of Nutrisphere $^{\mathrm{TM}}$ ranged from 0.5 to $1.3 \mathrm{Mg} \mathrm{ha}^{-1}$. The only trial in which the quadratic-plateau model found that $30 \%$ UAN resulted in a higher yield was in Pamlico09, when $\mathrm{N}$ rates were applied at planting. The trial at Beaufort09 when $\mathrm{N}$ was applied at planting was particularly interesting because the model indicated that the use of Nutrisphere ${ }^{\mathrm{TM}}$ resulted in more yield $(0.5 \mathrm{Mg}$ $\mathrm{ha}^{-1}$ more yield when Nutrisphere ${ }^{\mathrm{TM}}$ was used), but required $20.8 \mathrm{~kg} \mathrm{ha}^{-1}$ less $\mathrm{N}$ to achieve that yield. This was the only trial and only $\mathrm{N}$ solution in which maximum yield was greater with a lower optimum $\mathrm{N}$ rate.

\subsection{Tissue $\mathbf{N}$ Concentration, Biomass and $\mathbf{N}$ Uptake}

Statistical analysis of tissue concentrations, biomass and $\mathrm{N}$ uptake collected from plots that received $\mathrm{N}$ at planting at Pamlico09 indicated that the only significant treatment factor was $\mathrm{N}$ rate. At both V5 and $\mathrm{R} 1$ tissue samples collected from plots with $\mathrm{N}$ rates of 101, 146 and $202 \mathrm{~kg} \mathrm{~N}$ ha ${ }^{\mathrm{TM}}$ had higher $\mathrm{N}$ concentrations than samples collected from the zero rate treatment (Fig. 5). The same was true for both biomass and $\mathrm{N}$ uptake, where measurements collected from three $\mathrm{N}$ rate treatments were always greater than that measured in the zero rate plot.

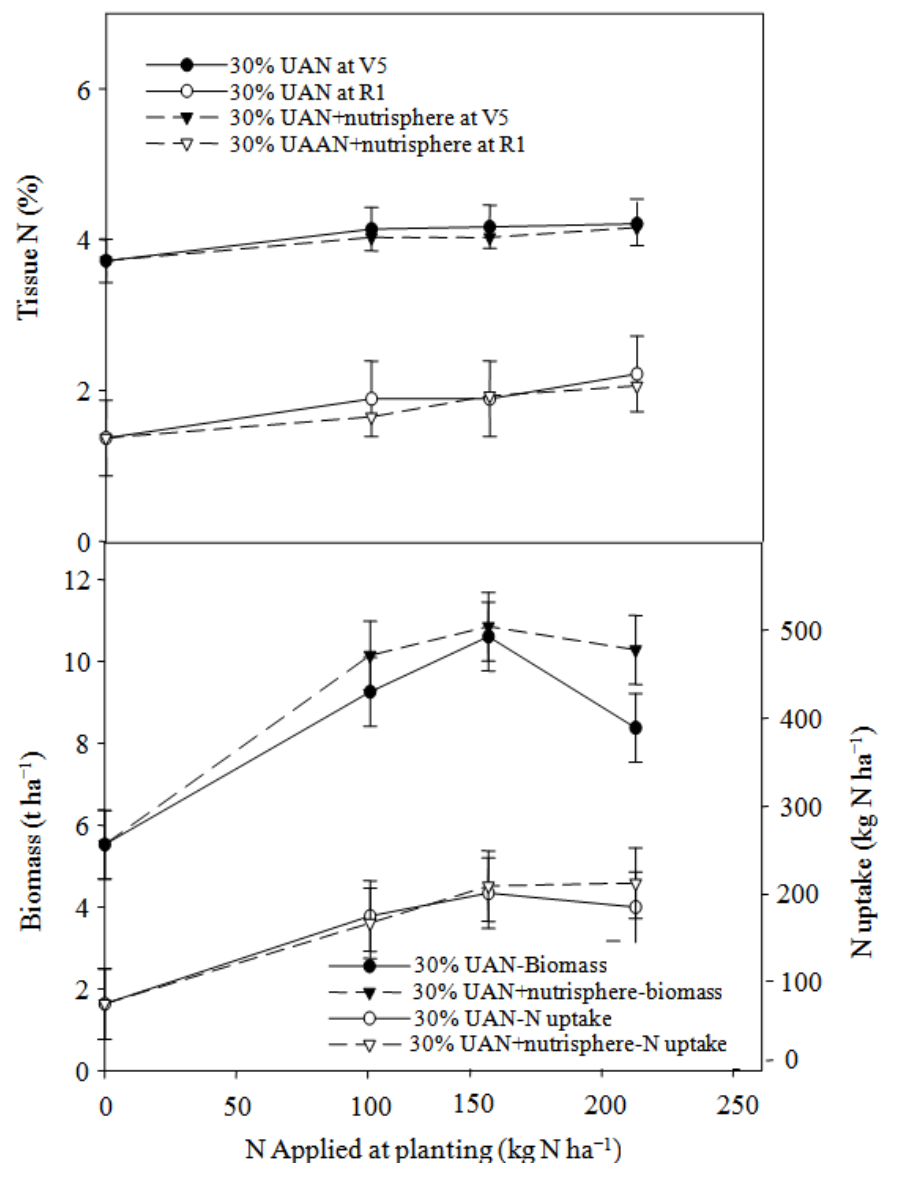

Fig. 5. Responses of tissue $\mathrm{N}$ concentration measured at V5 and R1, plant biomass measured at R1 and nitrogen uptake measured at $\mathrm{R} 1$ to $30 \%$ UAN applied with or without Nutrisphere ${ }^{\mathrm{TM}}$ at planting at Beaufort in 2009. Error bars represent significant differences at $\mathrm{p}<0.05$ 
In the case of stalk nitrate content, no statistical differences were found among the $\mathrm{N}$ rate treatments. At Pamlico09, there were no significant differences between $30 \%$ UAN and $30 \%$ UAN plus Nutrisphere ${ }^{\mathrm{TM}}$ for tissue $\mathrm{N}$ concentration measured either at V5 or R1, $\mathrm{N}$ uptake, or stalk nitrate content. In general, biomass tended to be greater when Nutrisphere ${ }^{\mathrm{TM}}$ was used and contrast statements indicated a significant $(\mathrm{p}=0.0682)$ difference between $30 \%$ UAN and $30 \%$ UAN plus Nutrisphere ${ }^{\mathrm{TM}}$ when $202 \mathrm{~kg} \mathrm{~N}^{-1}$ was applied.

At Beaufort09, $\mathrm{N}$ rate was the only significant factor when tissue $\mathrm{N}$ concentrations were measured either at V5 ( $p<0.0001)$ or R1 $(\mathrm{p}=0.0006)$. Similar to the Pamlico09 location, three higher $\mathrm{N}$ rates of 101, 146 and $202 \mathrm{~kg} \mathrm{~N} \mathrm{ha}^{-1}$ had greater tissue $\mathrm{N}$ concentrations when compared to plots with no applied N (Fig. 6). There was a significant $\mathrm{N}$ solution by $\mathrm{N}$ rate interaction for biomass. While biomass did not differ between the two $\mathrm{N}$ solutions when either no $\mathrm{N}$ or $101 \mathrm{~kg} \mathrm{~N} \mathrm{ha}^{-1}$ were applied, there were significant differences in biomass between $30 \%$ UAN and 30\% UAN plus Nutrisphere ${ }^{\mathrm{TM}}$ at the two higher $\mathrm{N}$ rates of 146 and $202 \mathrm{~kg} \mathrm{~N} \mathrm{ha}^{-1}$. A similar observation was made by Cahill et al. (2010). This indicates that the use of Nutrisphere ${ }^{\mathrm{TM}}$ does affect plant growth. Despite the significant increase in biomass, statistical analysis did not find a significant $\mathrm{N}$ solution by $\mathrm{N}$ rate interaction for $\mathrm{N}$ uptake. Contrast statements indicated that there were differences in $\mathrm{N}$ uptake between the $\mathrm{N}$ solutions at $\mathrm{N}$ rates of 146 and $202 \mathrm{~kg} \mathrm{~N}$ $\mathrm{ha}^{-1}(\mathrm{p}=0.0752$ and 0.0620 , respectively). There was also a significant rate affect. The $\mathrm{N}$ uptake was greatest at $\mathrm{N}$ rates of 146 and $202 \mathrm{~kg} \mathrm{~N} \mathrm{ha}^{-1}$. There were no significant differences among $\mathrm{N}$ rates or between the $\mathrm{N}$ solutions for stalk nitrate content.

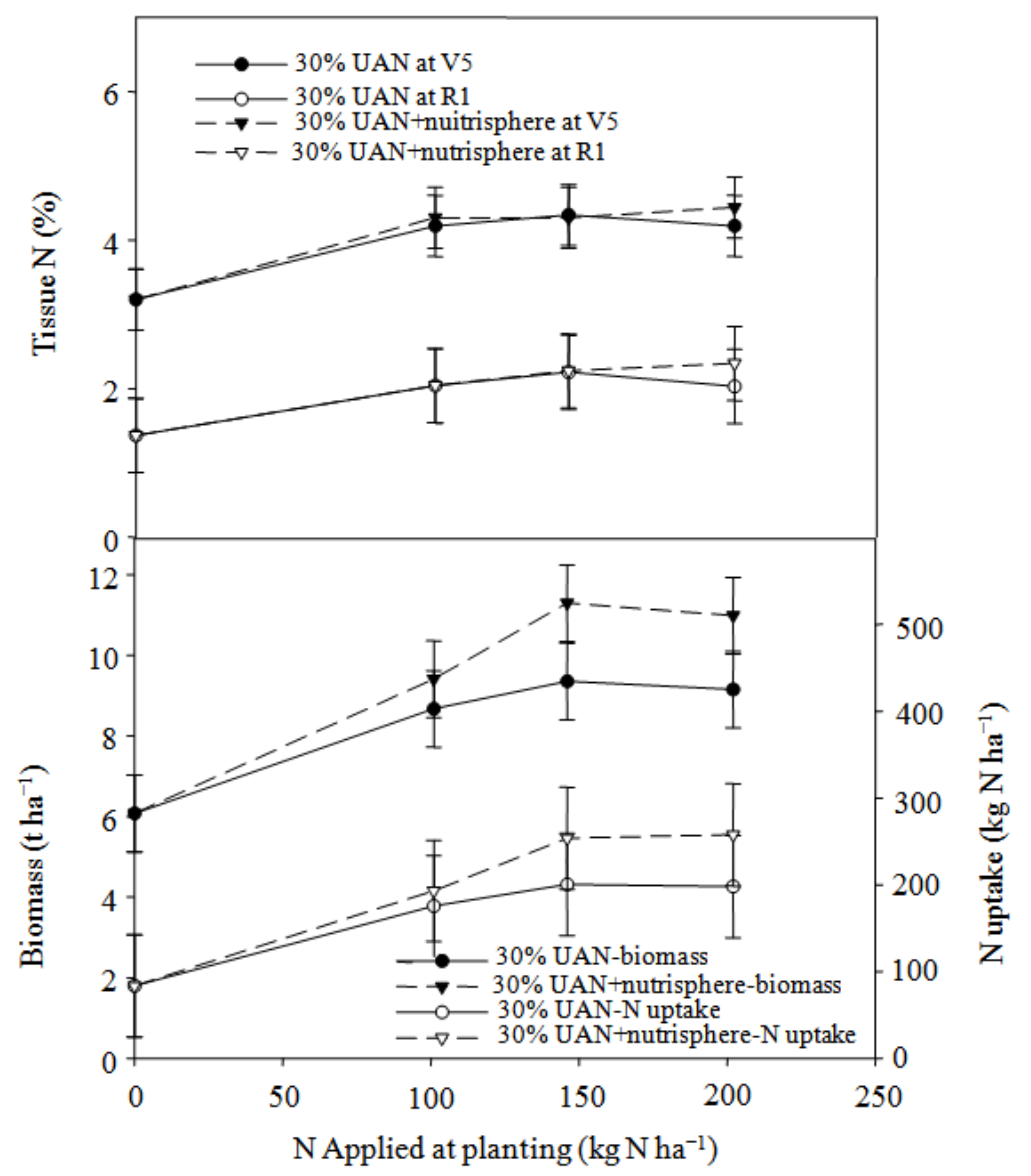

Fig. 6. Responses of tissue $\mathrm{N}$ concentration measured at V5 and R1, plant biomass measured at R1 and nitrogen uptake measured at $\mathrm{R} 1$ to $30 \%$ UAN applied with or without Nutrisphere ${ }^{\mathrm{TM}}$ at planting at Beaufort in 2009. Error bars represent significant differences at $\mathrm{p}<0.05$ 


\section{DISCUSSION}

A review of synthetic slow and controlled release fertilizer literature suggests that yield increases or improvements in nutrient efficiency do occur, but only under certain weather or field conditions. On a sandy soil, Wen et al. (2001) found greater peanut (Arachis hypogaea L. cv. Hanritusei) yield and $\mathrm{N}$ recovery with resin-coated $\mathrm{N}$ fertilizer. In field and laboratory studies using conditions favorable to ammonium volatilization, Vaio et al. (2008) measured $\mathrm{NH}_{3}$ losses from urea formaldehyde polymer and found that less $\mathrm{NH}_{3}$ was lost. A two-year potato study on an irrigated loamy sand using Environmental Smart Nitrogen (ESN), polymer coated urea and a blend of urea and ammonium nitrate, found that optimum $\mathrm{N}$ rates were less for ESN than soluble $\mathrm{N}$ and potato yields under ESN were similar to those from split applied N (Wilson et al., 2009). In years with above average rainfall Wiedenfeld (1986) found that cabbage (Brassica oleracea L. Group capitata) and onion (Allium cepa L.) had increased yield, yield weight and leaf $\mathrm{N}$ content when grown with slow-release fertilizers, methylene urea and sulfur-coated urea, but there were no differences when rainfall was below average. Halvorson et al. (2008) studied $\mathrm{N}_{2} \mathrm{O}$ gas flux emission from irrigated corn (Zea mays L.), wheat (Triticum aestivum L.), barley (Hordeum vulgare) and dry bean (Phaseolus vulgaris) treated with various $\mathrm{N}$ fertilizers on clay loam in the western great plains. Under irrigation, the polymer coated urea reduced $\mathrm{N}_{2} \mathrm{O}$ emissions from the four irrigated crops. Kondo et al. (2005) compared split applications of urea with polyolefin resincoated urea and found that apparent $\mathrm{N}$ recovery fraction improved with the polyolefin resin-coated urea due to less leaching under heavy rainfall or irrigation. A two-year field trial using ESN, found that on a claypan soil, ESN increased corn grain yields in a wet, low-lying field position when compared to urea (Noellsch et al., 2009). It is clear from this review that the benefits from the use of these controlled release fertilizers or fertilizer additives depend on the weather, soil and management conditions under which these products are applied.

While comparative research on corn done at Kansas State University (Gordon, unpublished data), University of Illinois (Ebelhar, unpublished data) and other institutions (Randall, unpublished data) indicates that Nutrisphere ${ }^{\mathrm{TM}}$ improved corn yield on a wide variety of soil types, other studies have not found improvements in yield or nutrient use efficiency on rice (Mississippi and Arkansas, unpublished data) or delays in $\mathrm{N}$ release (Cahill et al., 2010) or volatilization (Binford, unpublished data). Cahill et al. (2010) found that Nutrisphere ${ }^{\mathrm{TM}}$ did not improve $\mathrm{N}$ use efficiency in either wheat or corn, but that Nutrisphere ${ }^{\mathrm{TM}}$ did increase stover yield in corn. This was the result of earlier season vegetative growth, which did not correspond to increased yield.

\section{CONCLUSION}

Research studies at six locations across three years where $\mathrm{N}$ was applied either at planting or layby (or both) indicated that the use of Nutrisphere ${ }^{\mathrm{TM}}$ as an additive to $30 \%$ UAN did result in modest increases in corn yield ranging from 0.05 to $0.74 \mathrm{Mg} \mathrm{ha}^{-1}$. Numerical increases in corn yield, when Nutrisphere ${ }^{\mathrm{TM}}$ was added, were noted at mostly every $\mathrm{N}$ rate applied at every location in each year and at both planting and layby, although there were only four instances when these differences were significant. In 2008, study combining Nutrisphere ${ }^{\mathrm{TM}}$ with a test of starter fertilizer with and without Avail ${ }^{\mathrm{TM}}$ also found significant increases in yield. As indicated by the biomass data collected at Beaufort09 and Pamlico09, differences in corn yield were the generally the result of higher growth. At Beaufort09, $\mathrm{N}$ uptake was also greater at higher $\mathrm{N}$ rates indicating that more of the fertilizer $\mathrm{N}$ was utilized by the plant. This resulted in greater $\mathrm{N}$ use efficiency at that location (less $\mathrm{N}$ required to achieve optimum yield). Cahill et al. (2010) also noted greater biomass in corn when Nutrisphere ${ }^{\mathrm{TM}}$ was applied with $30 \%$ UAN. Observations of early growth advantages in plots receiving Nutrisphere ${ }^{\mathrm{TM}}$ at planting lead to the conclusion that addition of Nutrisphere ${ }^{\mathrm{TM}}$ results in more $\mathrm{N}$ reaching the root surface and entering the plant.

Comparisons of optimum $\mathrm{N}$ rates and maximum corn yield between treatments of 30 and 30\% UAN plus Nutrisphere ${ }^{\mathrm{TM}}$ also tend to support the indications that the use of Nutrisphere ${ }^{\mathrm{TM}}$ has its greatest impact on plant growth and increasing potential yield. While Nutrisphere ${ }^{\mathrm{TM}}$ did reduce optimum $\mathrm{N}$ rate in two trials the most consistent trend was that higher maximum corn yields were achieved when Nutrisphere ${ }^{\mathrm{TM}}$ was applied. This indicates that greater yield advantages will be found when Nutrisphere ${ }^{\mathrm{TM}}$ is used under conditions, where yield is not limited by lack of rainfall or other factors. This may be the reason for conflicting results found when testing the impact Nutrisphere ${ }^{\mathrm{TM}}$ on yield.

The rapid growth response to the addition of Nutrisphere ${ }^{\mathrm{TM}}$ resulted in the lack of differences in tissue $\mathrm{N}$ concentration. However, even though plant growth was affected to some extent at both Pamlico09 and Beaufort09 locations, total $\mathrm{N}$ uptake was only different 
at the two higher $\mathrm{N}$ rates at the Beaufort09 location. This seems to indicate that the impact of Nutrisphere ${ }^{\mathrm{TM}}$ in affecting $\mathrm{N}$ uptake by the plant occurs over a fairly short period. It is clear that more study is needed to determine how Nutrisphere ${ }^{\mathrm{TM}}$ is impacting $\mathrm{N}$ movement, transformation and uptake, so that better recommendations can be made regarding its use and potential for increasing yield.

\section{ACKNOWLEDGEMENT}

Reachers would like to thank the Specialty Fertilizer Products (SFP) for financial support in conducting field research.

\section{REFERENCES}

Blackmer, T.M. and J.S. Schepers, 1996. Aerial photography to detect nitrogen stress in corn. J. Plant Physiol., 148: 440-444. DOI: 10.1016/S01761617(96)80277-X

Cahill, S., D. Osmond, R. Weisz and R. Heiniger, 2010. Evaluation of alternative nitrogen fertilizers for corn and winter wheat production. Agron. J., 102: 12261326. DOI: 10.2134 /agronj2010.0095

FAO, 2004. The State of Food Insecurity in the World. Rome.

Halvorson, A.D., S.J. Del Grosso and C.A. Reule, 2008. Nitrogen, tillage and crop rotation effects on nitrous oxide emissions from irrigated cropping systems. J. Environ. Q., 37: 1337-1344. DOI: 10.2134/jeq2007.0268

Hubbard, R.K. and J.M. Sheridan, 1989. Nitrate movement to groundwater in the Southeastern coastal plain. J. Soil Water Conserv., 44: 20-27.

Jarecki, M.K., T.B. Parkin, A.S.K. Chan, J.L. Hatfield and R. Jones, 2008. Greenhouse Gas emissions from two soils receiving nitrogen fertilizer and swine manure slurry. J. Environ. Q., 37: 1432-1438. DOI: 10.2134/jeq2007.0427

Kondo, M., C.V. Singh, R. Agbisit and M.V.R. Murty, 2005. Yield response to urea and controlled-release urea as affected by water supply in tropical upland rice. J. Plant Nutr., 28: 201-219. DOI: 10.1081/PLN200047601
NASS, 2009. Agricultural Chemical Usage 2008 Field Crops Summary.

Nelson, D.W. and L.E. Sommers, 1973. Determination of total nitrogen in plant material. Agron. J., 65: 109-112.

Noellsch, A.J., P.P. Motavalli, K.A. Nelson and N.R. Kitchen, 2009. Corn response to conventional and slow-release nitrogen fertilizers across a claypan landscape. Agron. J., 101: 607-614. DOI: 10.2134/agronj2008.0067x

SAS, 2005. SAS Online Doc 9.1.3. SAS Institute Inc. Cary, NC.

Stevenson, C.K. and C.S. Baldwin, 1969. Effect of time and method of nitrogen application and source of nitrogen on the yield and nitrogen content of corn (Zea mays L.), Agron. J., 61: 381384.

DOI: 10.2134/agronj1969.00021962006100030014x

Trenkel, M.E., 1997. Controlled-release and stabilized fertilizers in agriculture. International Fertilizer Industry Association. Paris, France.

Vaio, N., M.L. Cabrera, D.E. Kissel, J.A. Rema and J.F. Newsome et al., 2008. Ammonia volatilization from urea-based fertilizers applied to tall fescue pastures in Georgia USA. Soil Sci. Soc. Am. J., 72: 1665-1671. DOI: 10.2136/sssaj2007.0300

Wen, G., T. Mori, T. Yammamoto, J. Chikushi and M. Inoue, 2001. Nitrogen recovery of coated fertilizers and influence on peanut seed quality for peanut plants grown in sandy soil. Commun. Soil Sci. Plant Anal., 32: 3121-3140. DOI: 10.1081/CSS120001111

Wiedenfeld, R.P., 1986. Rate, timing and slow-release nitrogen fertilizers on cabbage and onions. Hort. Sci., 21: 236-238.

Wilson, M.L., C.J. Rosen and J.F. Moncrief, 2009. Potato response to polymer-coated urea on an irrigated, coarse textured soil. Agron. J., 101: 897905. DOI: 10.2134/agronj2008.0192x 